\title{
Reply to the Letter to the Editor: Extraperitoneal cesarean section and transperitoneal cesarean section: does extraperitoneal technique shorten the duration of surgical operation?
}

Dear Editor,

We would like to thank Dr. Sargin, the author of Letter to the Editor, ${ }^{[1]}$ for her interest in our extraperitoneal cesarean section. We would to explain following matters for the clarification of the topic and the related cesarean section procedure.

The operator, in the said publication, gained the experience in the institution first that he specialized, and the other institutions that he has worked so far. He has an experience of a 20-case series. One of these 20 cases had peritoneum perforation.

The patient decided for the technique to be applied. The patient was informed about the anatomy of anterior abdominal wall, the definition of peritoneum and the possible advantages on intraoperative nausea-vomiting and postoperative pain by not entering into abdominal cavity. ${ }^{[2]}$ Although the number of cesarean section procedures is high in the stated center, most of them were not the cases of which records were kept completely.

The cases with the history of cephalopelvic disproportion, breech presentation and previous cesarean section which are the cesarean section and labor indications were included in the study. The cases with the history of abdominal surgery except cesarean section, multiple pregnancy, preterm labor before 34 weeks of gestation, placenta previa, the need for emergency cesarean section, transverse presentation, macrosomic fetus, the suspicion of placental attachment anomalies and body mass index above 35 were excluded from the study. The same criteria were used for the control group as well. In the technique, the region between rectus muscle and parietal peritoneum is dissected, and then the bladder is reached. The bladder is eliminated laterally by a blunt dissection and it is entered into the vesico-uterine area, and then uterus is reached through lower segment transverse incision. We used the technique described by Tappauf et al. in their study. ${ }^{[2]}$ Shorter surgery duration in the extraperitoneal group is consistent with the current literature ${ }^{[2-4]}$ We believe that the shorter surgery duration in the extraperitoneal cesarean section group may be associated with the potential reasons such as the absence of peritoneal cleaning, intestines not blocking surgical area due to spinal anesthesia, and not closing visceral and parietal peritoneum. The reason for not including the cases which underwent emergency cesarean section is the failure of providing appropriate conditions to inform the emergency cases about the technique.

We would like to thank the author of the Letter to the Editor for this opportunity to make a detailed explanation about our study.

Kind regards,

Cengiz Yeşilbaş

Clinic of Obstetrics and Gynecology, Batman Private Zilan Hospital, Batman, Turkey

Hakan Erenel Department of Obstetrics and Gynecology, Cerrahpaşa Faculty of Medicine, Istanbul University-Cerrahpaşa, İstanbul, Turkey

Conflicts of Interest: No conflicts declared

Correspondence: Cengiz Yeşilbaş, MD. Clinic of Obstetrics and Gynecology, Batman Private Zilan Hospital, Batman, Turkey. e-mail: dr.cyesilbas@gmail.com / Received: May 5, 2020; Accepted: May 10, 2020

Please cite this article as: Yeşilbaş C, Erenel H. Reply to the Letter to the Editor: Extraperitoneal cesarean section and transperitoneal cesarean section: does extraperitoneal technique shorten the duration of surgical operation? Perinatal Journal 2020;28(2):146-147. doi:10.2399/prn.20.0282003 


\section{References}

1. Sargin FB. Letter to the Editor: Extraperitoneal versus transperitoneal cesarean section: a retrospective analysis. Perinatal Journal 2020;28:145. [CrossRef]

2. Tappauf C, Schest E, Reif P, Lang U, Tamussino K, Schoell W. Extraperitoneal versus transperitoneal cesarean section: a prospective randomized comparison of surgical morbidity. Am J Obstet Gynecol 2013;209:338.e1-e8. [PubMed] [CrossRef]

3. Yapca OE, Topdagi YE, Al RA. Fetus delivery time in extraperitoneal versus transperitoneal cesarean section: a randomized trial. J Matern Fetal Neonatal Med 2020;33: 657-63. [PubMed] [CrossRef]

4. Hanson HB. Current use of the extraperitoneal cesarean section: a decade of experience. Am J Obstet Gynecol 1984;149: 31-4. [PubMed] [CrossRef]

Bu makalenin kullanım izni Creative Commons Attribution-NoCommercial-NoDerivs 3.0 Unported (CC BY-NC-ND3.0) lisansı aracılığıla bedelsiz sunulmaktadır. / This work is licensed under the Creative Commons Attribution-NonCommercial-NoDerivs 3.0 Unported (CC BY-NC-ND3.0) License. To view a copy of this license, visit http://creativecommons.org/licenses/by-nc-nd/3.0/ or send a letter to Creative Commons, PO Box 1866, Mountain View, CA 94042, USA. 